\title{
The Influence of Micro- and Nano-Filler Content on the Mechanical Properties of Epoxy Composites
}

\author{
Iskender Ozsoy ${ }^{1}$ - Askin Demirkol, ${ }^{1, *}$ - Abdullah Mimaroglu ${ }^{1}$ - Huseyin Unal ${ }^{1}$ - Zafer Demir ${ }^{2}$ \\ 1,* University of Sakarya, Faculty of Engineering, Turkey \\ 2 University of Anadolu, Porsuk High School, Turkey
}

In this study, the influence of micro- and nano-filler content on the mechanical properties of epoxy composites was studied. The matrix material is epoxy; the micro-fillers are $\mathrm{Al}_{2} \mathrm{O}_{3}, \mathrm{TiO}_{2}$ and fly ash added in $10 \mathrm{wt} \%$ to $30 \mathrm{wt} \%$ by weight ratio; the nano-fillers are $\mathrm{Al}_{2} \mathrm{O}_{3}, \mathrm{TiO}_{2}$ and clay added in $2.5 \mathrm{wt} \%$ to $10 \mathrm{wt} \%$ by weight ratio. Test samples were prepared using an open mould type die. Tensile, three-point bending and hardness tests were carried out. The tensile strength, elastic modulus, elongation at break, flexural strength, flexural modulus, and the hardness of the composite materials were obtained and evaluated. The results show that the tensile strength, flexural strength and elongation at the break values of composites decreased while the tensile modulus and flexural modulus increased with the increasing micro- and nano-filler content ratio.

Keywords: micro-filler; nano-filler; mechanical properties; epoxy; composite

Highlights

- $\quad$ This paper highlights possible reasons for variations in the mechanical properties of composites filled with nano- and microfiller to compare the mechanical property of composites containing various amounts of nano-and micro-fillers.

- Small amounts of nano-size particles in epoxy have a strong effect on both tensile and flexural strength as well as ductility.

- Agglomeration problems have been observed at a higher amounts of filler ratios in composites.

\section{O INTRODUCTION}

Various fillers have been used to design the desired properties in the polymer matrix. These fillers are mineral fillers, agricultural and/or puzzolanic wastes. In this field, researchers have studied the effects of particle shape, filler type, size, content ratio, and adhesion between matrix and fillers on the mechanical properties of polymer composites. Zaman et al. [1] studied the micro- and nano- ZnO-filled polypropylene composites with filler ratios between $2 \mathrm{wt} \%$ to $8 \mathrm{wt} \%$. Nano-filled composites showed better results than micro-filled composites at the same filler ratios. They stated that the dispersion of particles is optimal in the $5 \mathrm{wt} \%$ filler content because the morphology images and dispersion of nano-fillers were better, which led to stronger interfacial adhesion between matrix and fillers. Gao et al. [2] studied nano- $\mathrm{CaCO}_{3}$-filled polystyrene composites. They concluded that fillers added stiffness to the polymer composite, but increasing the filler ratio beyond that point caused an agglomeration of particles, which decreased the adhesion between matrix and fillers and caused a drop in the mechanical strength of the composite. Agubra et al. [3] investigated the effects of dispersion methods on the mechanical behaviour of nano-clay-filled glass fibre epoxy composites. They stated that increasing viscosity causes problems in the homogeneous dispersion of fillers and results in the agglomeration of the filler particles. Lam et al. [4] studied the hardness values of nano-clay-filled epoxy composites. They stated that the hardness values of the composite is increased by adding nanoclay fillers up to a limit and then decreased because of clusters at the high filler ratios. Yasmin and Daniel [5] investigated graphite-filled epoxy composites with $2.5 \%$ to $5 \%$ by weight filler ratios. They concluded that the tensile strength and modulus of the composite are increased by adding fillers, and an agglomeration of fillers occurred at a $5 \mathrm{wt} \%$ filler ratio. Sayer [6] used ceramic fillers, such as $\mathrm{SiC}, \mathrm{Al}_{2} \mathrm{O}_{3}$, and $\mathrm{B}_{4} \mathrm{C}$, in the glass-reinforced epoxy resin. He concluded that the elastic modulus and buckling load carrying capability of composites were increased by adding ceramic fillers. Asi [7] studied the mechanical properties of $\mathrm{Al}_{2} \mathrm{O}_{3}$-filled glass fibre-reinforced epoxy composites. He concluded that the tensile strength of composites decreased with the addition of $\mathrm{Al}_{2} \mathrm{O}_{3}$ fillers. While the bending strength increased up to 10 $\mathrm{wt} \%$ filler ratio and decreased at higher ratios. Yang et al. [8] studied the mechanical properties of rice husk flour-filled polypropylene composites. They stated that high filler ratios increased the interfacial area and made the polymer composite brittle. Thus, the tensile and impact strength of the composites decreased while the tensile modulus increased. Ibrahim et al. [9] investigated oil palm ash-filled unsaturated polyester composites with $10 \mathrm{wt} \%$ to $30 \mathrm{vol} \%$ filler ratios. They 
observed an increase in the modulus and a decrease in the tensile and flexural strength of the composites with added filler materials. Li et al. [10] studied rice bran carbon/nitrile rubber composites. They investigated different particle size effects and reached a better dispersion with small particle fillers. Increasing the particle size and the filler ratio caused difficulties in the homogeneous dispersion of fillers, leading to weak adhesion between matrix and fillers. Imoisili et al. [11] investigated cocoa pod-filled epoxy composites with $5 \mathrm{wt} \%$ to $30 \mathrm{wt} \%$ filler ratios. They stated that the best dispersion of the filler was at the $5 \mathrm{wt} \%$ filler ratio. Furthermore, the mechanical strength values decreased while modulus and microhardness values increased when fillers were added. Ray et al. [12] studied the mechanical properties of fly ash-filled vinylester composites. They stated that the fly ash increased the stiffness and rigidity of composite, but the mechanical strength was reduced with a high content ratio. Raja et al. [13] studied fly ash-impregnated glass fibrereinforced polyester composites. The addition of 10 $\mathrm{wt} \%$ fly ash improved the mechanical properties of the composite. Chauhan and Thakur [14] investigated the filler size and loading effects on the mechanical and tribological performance of cenosphere-filled vinylester composites. They stated that the mechanical and tribological performance increased, and optimum values were obtained with a $6 \mathrm{wt} \%$ filler ratio. Prakash et al. [15] investigated the influence of microand nano-fillers on the mechanical properties of pultruded unidirectional glass fibre-reinforced epoxy composite systems and concluded that the improved mechanical properties indicate that the unidirectional glass fibre-reinforced epoxy with combined microand nanofiller-filled composite is a good candidate for structural application. Manjunath et al. [16] studied the effect of filler content on the performance of epoxy/PTW composites and concluded that PTW additions showed beneficiary effects on the density, hardness, and stiffness properties of composites; however, strength properties and ductility were found to decrease with the increasing content of PTW. Finally, Sudheer et al. [17] gave a general review of epoxy composites and particularly on ceria epoxy nanocomposites.

In this study, the influence of the micro- and nano-filler content ratios of the mechanical properties of epoxy composites was studied. For this purpose, tensile, three-point bending, and hardness tests were carried out. Tensile strength, elastic modulus, elongation at break, flexural strength, flexural modulus and the hardness of the epoxy composites were obtained and evaluated.

\section{EXPERIMENTAL}

\subsection{Materials}

In this study, epoxy resin is the polymer matrix material. Micro-fillers, such as aluminium oxide $\left(\mathrm{Al}_{2} \mathrm{O}_{3}\right)$, titanium dioxide $\left(\mathrm{TiO}_{2}\right)$ and fly ash, were added at a $10 \%$ to $30 \%$ by weight ratio. Nano-fillers, such as aluminium oxide $\left(\mathrm{Al}_{2} \mathrm{O}_{3}\right)$, titanium dioxide $\left(\mathrm{TiO}_{2}\right)$ and nanoclay, were added at $2.5 \%$ to $10 \%$ by weight ratios. The materials used and their properties are given in Table 1.

Table 1. Properties of materials used

\begin{tabular}{|c|c|c|c|}
\hline Materials & Properties & $\begin{array}{l}\text { Density } \\
{\left[\mathrm{gr} / \mathrm{cm}^{3}\right]}\end{array}$ & Supplier \\
\hline $\begin{array}{l}\text { Epoxy resin } \\
\text { (MGS L285) }\end{array}$ & Bisphenol A & 1.178 & $\begin{array}{l}\text { Dost Chemia } \\
\text { Co. }\end{array}$ \\
\hline Aluminium oxide $\left(\mathrm{Al}_{2} \mathrm{O}_{3}\right)$ & $45 \mu \mathrm{m}$ & 3.90 & $\begin{array}{l}\text { Eczacibası } \\
\text { Esan Co. }\end{array}$ \\
\hline $\begin{array}{l}\text { Titanium dioxide } \\
\left(\mathrm{TiO}_{2}\right)\end{array}$ & $50 \mu \mathrm{m}$ & 4.00 & $\begin{array}{l}\text { Sintas } \\
\text { Plastic Co. }\end{array}$ \\
\hline Fly ash & $45 \mu \mathrm{m}$ & 2.00 & $\begin{array}{l}\text { Kutahya } \\
\text { Cement Co. }\end{array}$ \\
\hline $\begin{array}{l}\text { Aluminium oxide } \\
\left(\mathrm{Al}_{2} \mathrm{O}_{3}\right)\end{array}$ & $40 \mathrm{~nm}$ & 3.88 & $\begin{array}{l}\text { Grafen } \\
\text { Chemia Co. }\end{array}$ \\
\hline $\begin{array}{l}\text { Titanium dioxide } \\
\left(\mathrm{TiO}_{2}\right)\end{array}$ & $\begin{array}{l}10 \mathrm{~nm}, \\
\text { anatase }\end{array}$ & 3.90 & $\begin{array}{l}\text { Grafen } \\
\text { Chemia Co. }\end{array}$ \\
\hline $\begin{array}{l}\text { Nanoclay (Montmorillonite } \\
\text { modified with Trimethyl } \\
\text { stearyl ammonium) }\end{array}$ & $\begin{array}{l}\text { Nanomer } \\
10 \mu \mathrm{m}\end{array}$ & 1.90 & $\begin{array}{l}\text { Sigma } \\
\text { Aldrich }\end{array}$ \\
\hline
\end{tabular}

\subsection{Composite Preparation}

In the composite material preparation process, the filler was dried in an oven at $70{ }^{\circ} \mathrm{C}$ for $4 \mathrm{~h}$. The epoxy resin was heated in order to reduce viscosity before mixing. Fillers were then added into the resin and mixed using mechanical stirrer for $2 \mathrm{~h}$. During this stage, vacuum processes were used to remove the entrapped air. After that, the hardener (Curing agent MGS LH 285) was added and mixed manually. The vacuum process was again applied. Afterwards, composite resin was poured into the open moulds. In the case of nano-filler, before the hardener was added, the resin was subjected to an ultrasonic method for 15 min. Finally, specimens in the moulds were tested at room conditions for $24 \mathrm{~h}$, following which they were placed in an oven and heated at $60{ }^{\circ} \mathrm{C}$ for $15 \mathrm{~h}$ and 80 ${ }^{\circ} \mathrm{C}$ for $5 \mathrm{~h}$ for post-curing in order to cross-link. 


\section{RESULTS}

Standard tensile tests were performed using a Shimadzu test machine with a crosshead speed of 5 $\mathrm{mm} / \mathrm{min}$ at room temperature $\left(23 \pm 1^{\circ} \mathrm{C}\right)$. The tensile strength value was determined according to the ASTM D638-10 standard [18]. The tensile strength, elastic modulus and strain [\%] values were obtained and evaluated. Three-point bending tests were carried out using a Shimadzu test machine according to the ASTM D790-10 [19] standard. The test specimen dimensions were $3.2 \mathrm{~mm} \times 12.7 \mathrm{~mm} \times 127 \mathrm{~mm}$ and the test speed was $2 \mathrm{~mm} / \mathrm{min}$. Flexural strength, flexural modulus, and elongation at break values were obtained and evaluated.

Flexural stress was calculated according to Eq. (1):

$$
\sigma=\frac{3 F L}{2 b d^{2}},
$$

where $\sigma$ is the flexural stress [MPa], $F$ is the load [N], $L$ is the span [mm], $b$ is the specimen width [mm] and $d$ is the specimen thickness [mm]. (2):

Flexural modulus was calculated according to Eq.

$$
E_{B}=\frac{L^{3} m}{4 b d^{3}},
$$

where $E_{B}$ is the flexural modulus [MPa], $L$ is the span $[\mathrm{mm}], b$ is the specimen width [mm], $d$ is the specimen thickness [mm], and $\mathrm{m}$ is the slope of the linear region of the load-displacement curve.

Bending strain was calculated according to Eq. (3):

$$
\varepsilon=\frac{6 D d}{L^{2}}
$$

where $\varepsilon$ is the strain $[\mathrm{mm} / \mathrm{mm}], D$ is the maximum displacement at the central point of the specimen, $d$ is the specimen thickness [mm], and $L$ is the span [mm].

Finally, the hardness test was carried out with a Barcol hardness tester according to the ASTM D258307 [20] standard.

All tests were repeated at least between 3 to 5 times, and the results were recorded and plotted, see Figs. 1 to 8 .

Fig. 1 presents the relationship between the tensile strength and filler content of micro- and nanoepoxy composites. It is clear that the tensile strengths of micro-filled composites decreased with increasing filler content ratio. The results also show the reduced sensitivity of the strength of $\mathrm{Al}_{2} \mathrm{O}_{3}$ filled composites to the change in filler content ratios. In the case of nanofiller, the strength is in an increase up to $2.5 \%$ filler content. This increase is about $8 \%$ and $12 \%$ for nano$\mathrm{TiO}_{2}$ and nano- $\mathrm{Al}_{2} \mathrm{O}_{3}$-filled composites, respectively. Beyond this ratio, there is some drop in the strength of the composite.

Fig. 2 shows the variation of tensile modulus of micro- and nano-filler composites with filler content. In this figure, the tensile modulus of epoxy composites

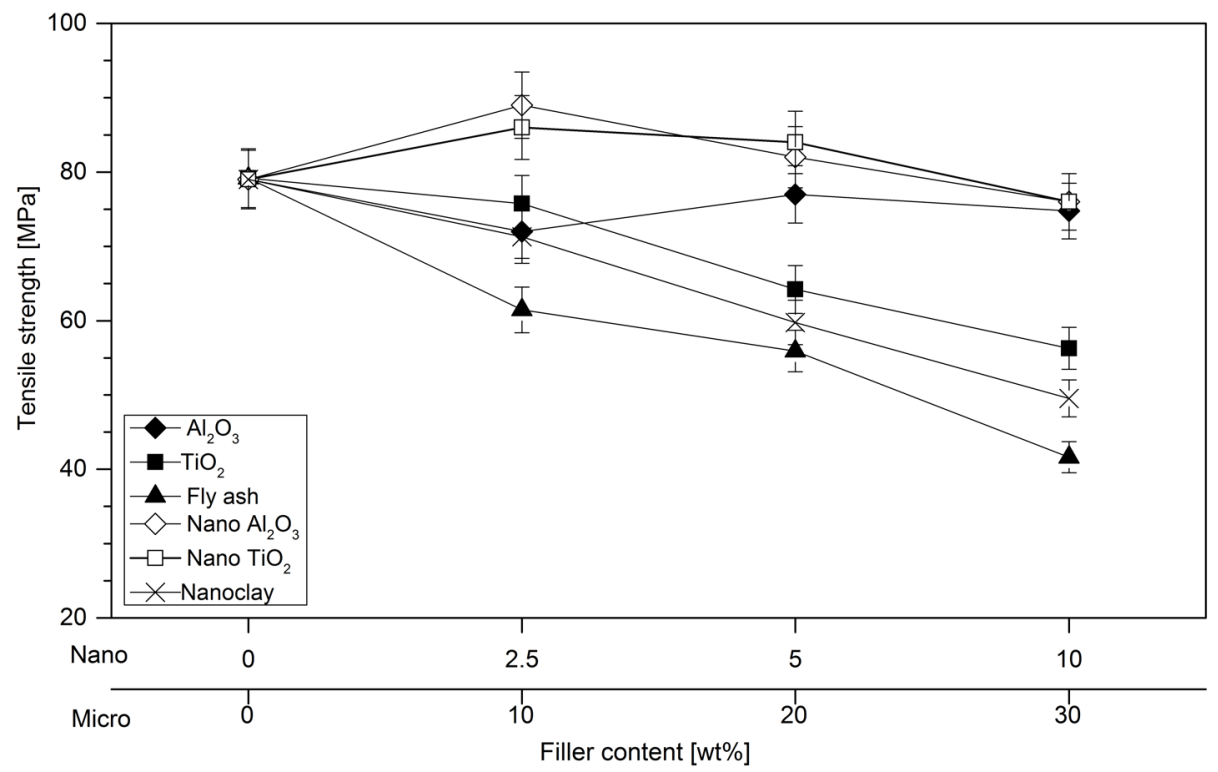

Fig. 1. The relationship of tensile strength against filler content of micro and nano epoxy composites 


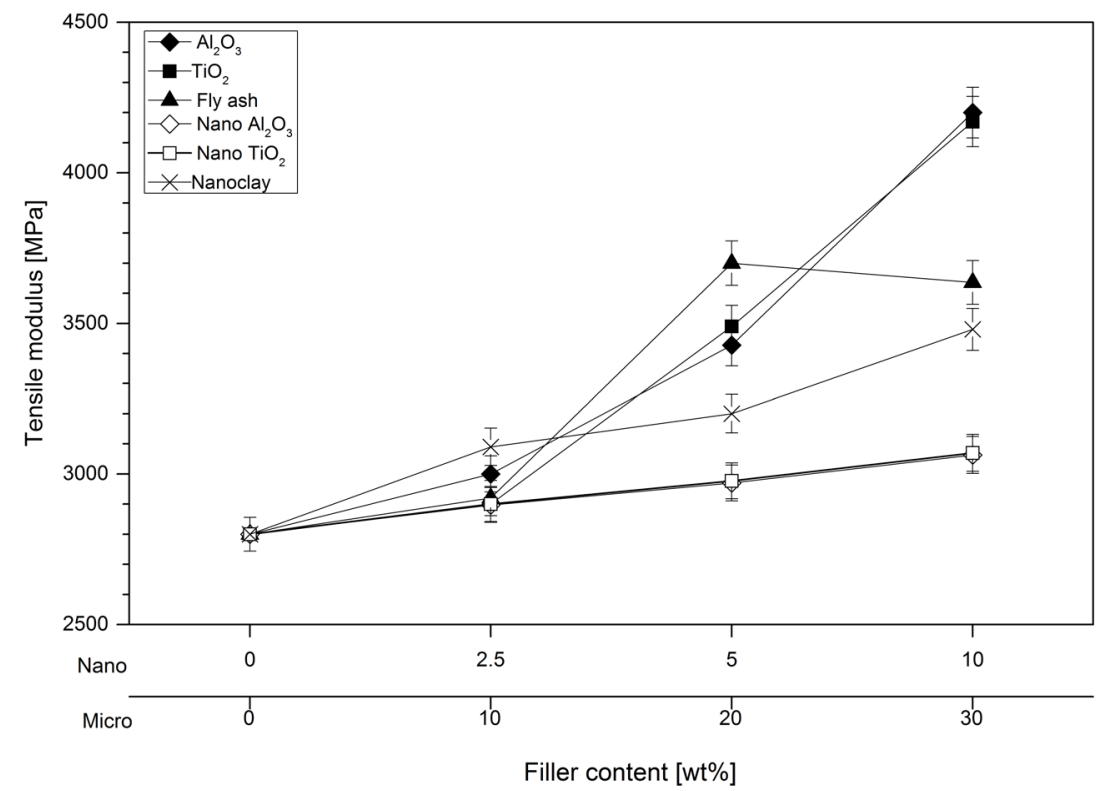

Fig. 2. The relationship of tensile modulus against filler content of micro and nano epoxy composites

increased with increasing filler content. Micro- and nano-fillers increased the polymer stiffness, and this increased its modulus. With a $200 \%$ increase in filler content, there is a $50 \%$ increase in the modulus for both $\mathrm{Al}_{2} \mathrm{O}_{3}$ - and $\mathrm{TiO}_{2}$-filled epoxy composites. In the case of nano-fillers, for a $300 \%$ increase in nanofiller content, the modulus of nano- $\mathrm{Al}_{2} \mathrm{O}_{3}$, nano- $\mathrm{TiO}_{2}$ and nano-clay increased by $9 \%, 9.6 \%$, and $24 \%$, respectively.
Fig. 3 presents the variation of elongation at break with filler content for micro- and nano-epoxy composites. It is clear from this figure that the elongation-at-break values decreased with increases of the filler content of the composite. The fillers gave the matrix the brittle behaviour. For a $200 \%$ increase in micro- $\mathrm{Al}_{2} \mathrm{O}_{3}, \mathrm{TiO}_{2}$ and fly ash filler content, the decreases in the elongation at break are $50 \%$, $66 \%$, and $65 \%$, respectively. For a $300 \%$ increase

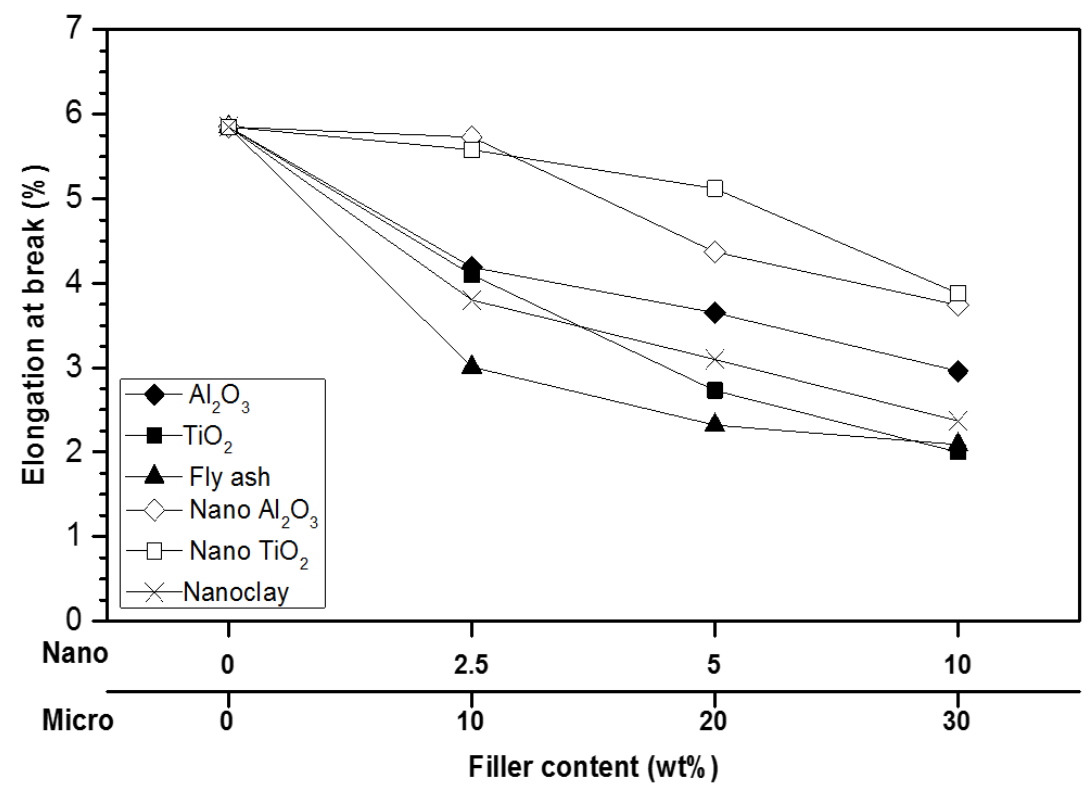

Fig. 3. The relationship of elongation at break against filler content of micro and nano epoxy composites 


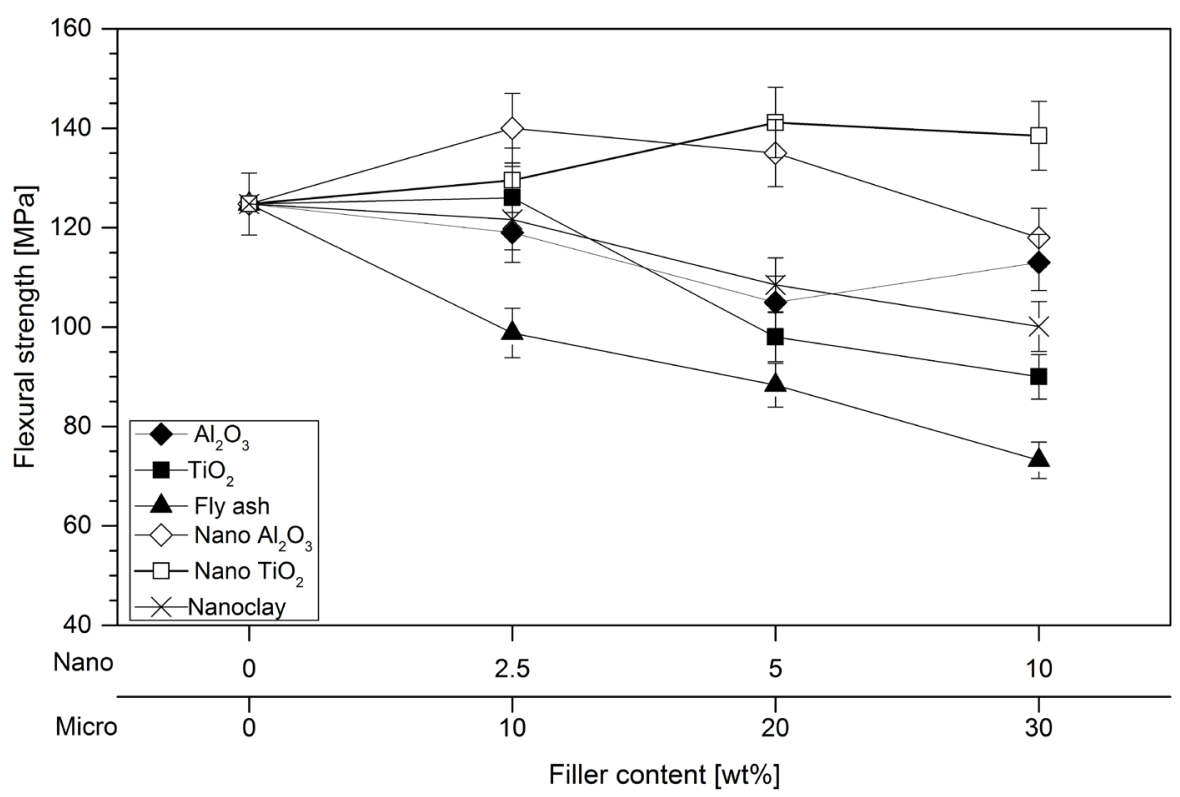

Fig. 4. The relationship of flexural strength against filler content of micro- and nano-epoxy composites

in nano- $\mathrm{Al}_{2} \mathrm{O}_{3}$, nano- $\mathrm{TiO}_{2}$ and nano-clay content, the decreases in the elongation at break are $37 \%, 34 \%$, and $60 \%$, respectively.

Fig. 4 shows the flexural strength against filler content curves of micro- and nano-epoxy composites. In this figure, the flexural strengths of microcomposites decreased with increasing filler content, and this decrease ranged between $12 \%$ to $45 \%$. The nano-composites follow an increasing trend up to
$2.5 \%$ to $5 \%$ ratios, and then a decreasing trend at higher filler ratios; $2.5 \mathrm{wt} \%$ filled nano $\mathrm{Al}_{2} \mathrm{O}_{3}$ showed the highest increase at $12 \%$. The nano- $\mathrm{TiO}_{2}$-filled composite reaches a $13 \%$ increase in flexural strength at $5 \mathrm{a} \mathrm{wt} \%$ filled ratio. The nano-clay-filled composite follows a decreasing trend, and this decrease reaches $20 \%$ at the $10 \%$ filler ratio.

Fig. 5 shows the relationship between the flexural modulus filler content of micro- and nano-epoxy

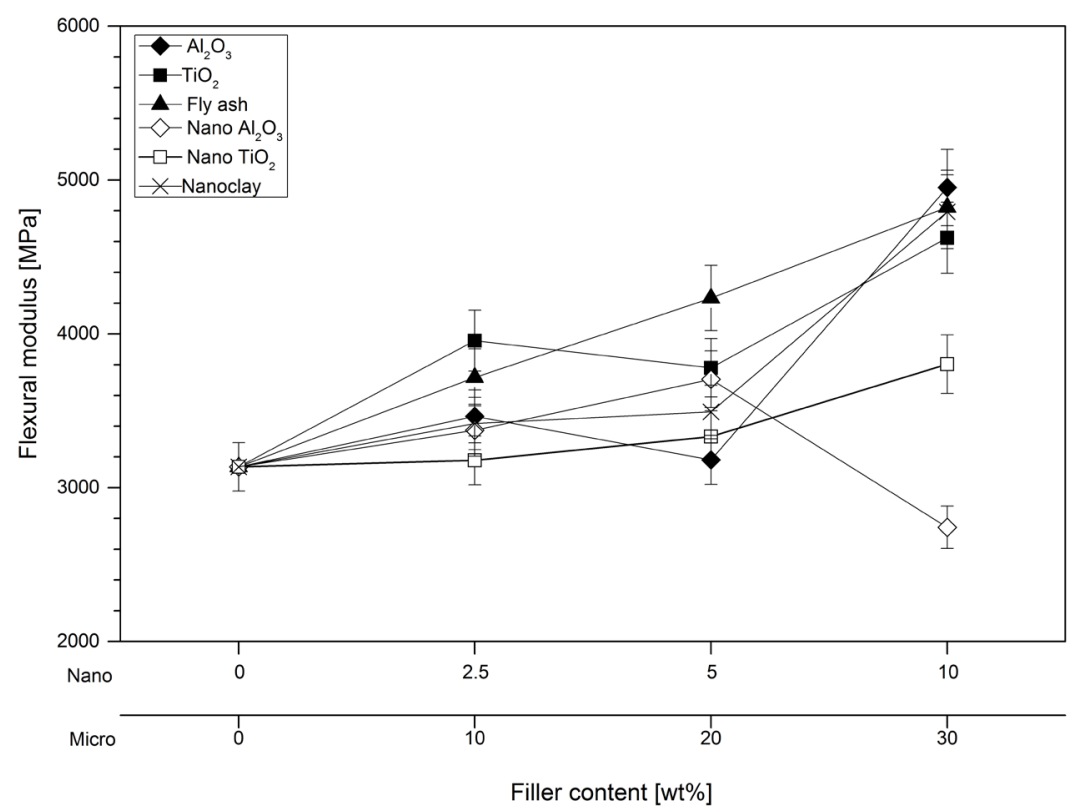

Fig. 5. The relationship of flexural modulus against filler content of micro and nano epoxy composites 


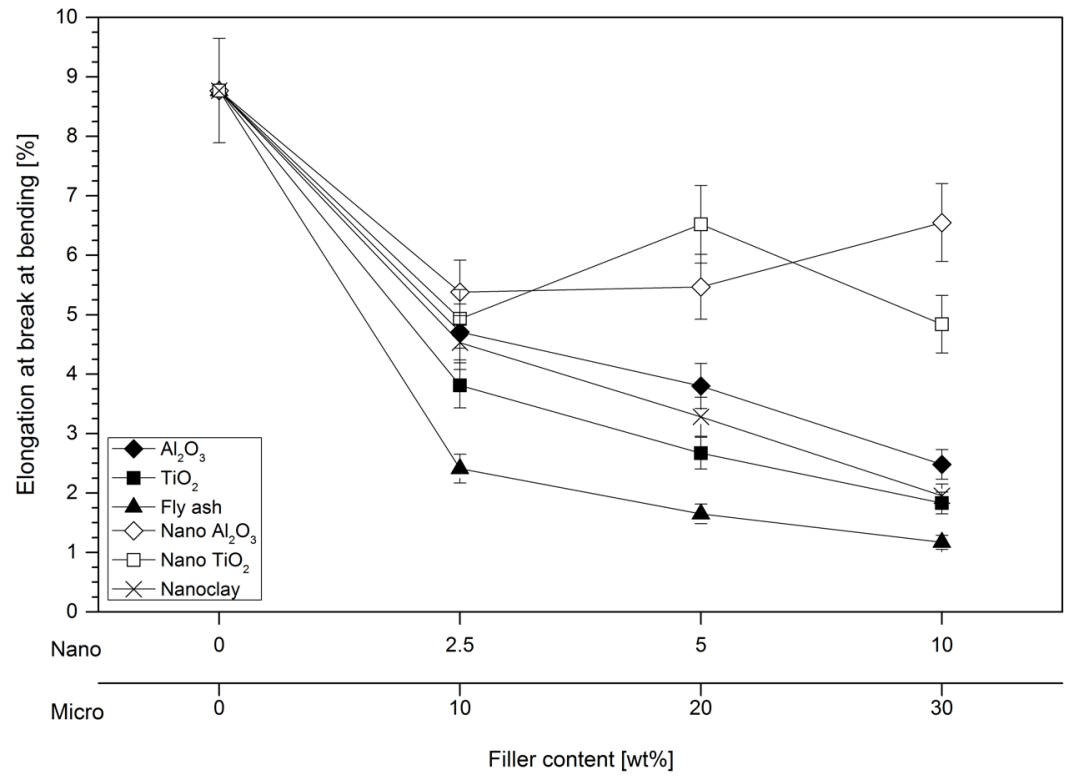

Fig. 6. The relationship of elongation at break at bending against filler content of micro and nano epoxy composites

composites. As the fillers increased the rigidity and stiffness behaviour in the polymer composite, the flexural modulus increased with the increasing filler content. The highest flexural modulus values were reached with $30 \mathrm{wt} \%$ micro-filler content composites. For a $200 \%$ increase in micro $\mathrm{Al}_{2} \mathrm{O}_{3}, \mathrm{TiO}_{2}$ and fly ash content, there are $57 \%, 47 \%$ and $53 \%$ increases in the flexural modulus of the composite, respectively. For a $300 \%$ increase in nano-filler content, there are $9 \%$ and $45 \%$ increases in nano- $\mathrm{TiO}_{2}$ and nano-clay epoxy composites flexural modulus, respectively. In the case of nano- $\mathrm{Al}_{2} \mathrm{O}_{3}$, there is an increasing and decreasing behaviour of $12 \%$.

Fig. 6 presents the variation of elongation at the break with filler content for micro- and nanoepoxy composites. As the presence of rigid fillers increased the matrix's brittle behaviour, which was reflected as reduced elongation at the break values of the materials, the figure shows that the minimum elongation at break values occurred at the maximum

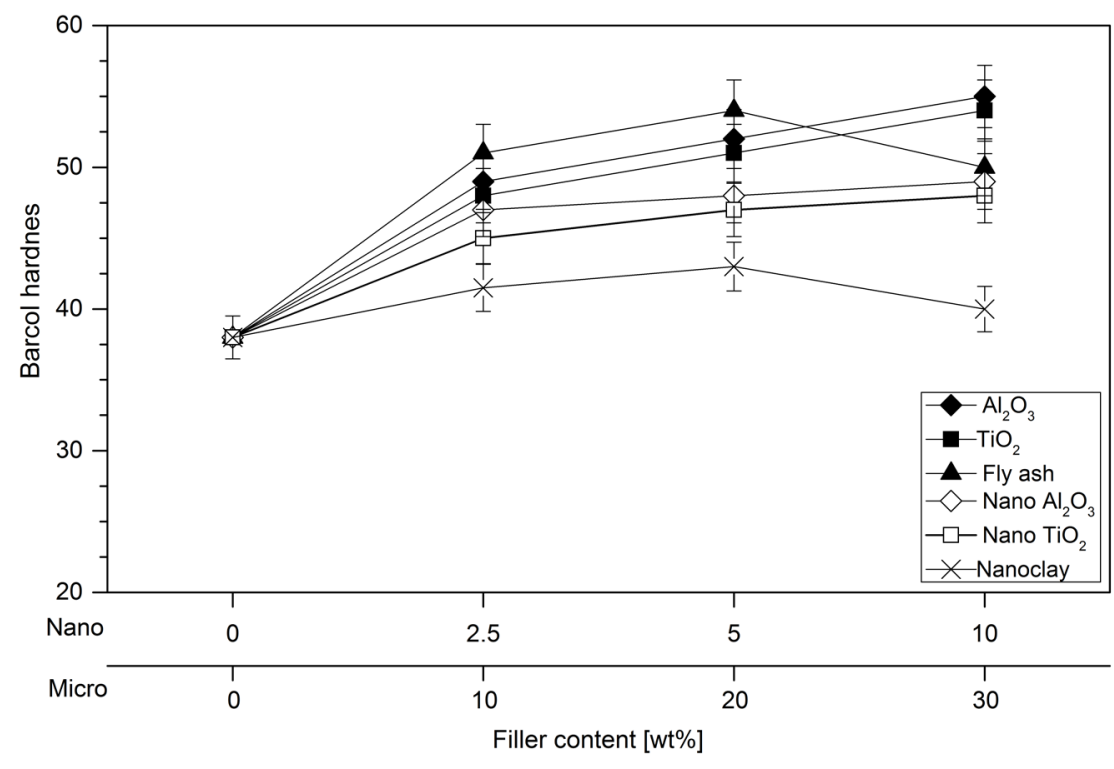

Fig. 7. The relationship of hardness against filler content of micro and nano epoxy composites 

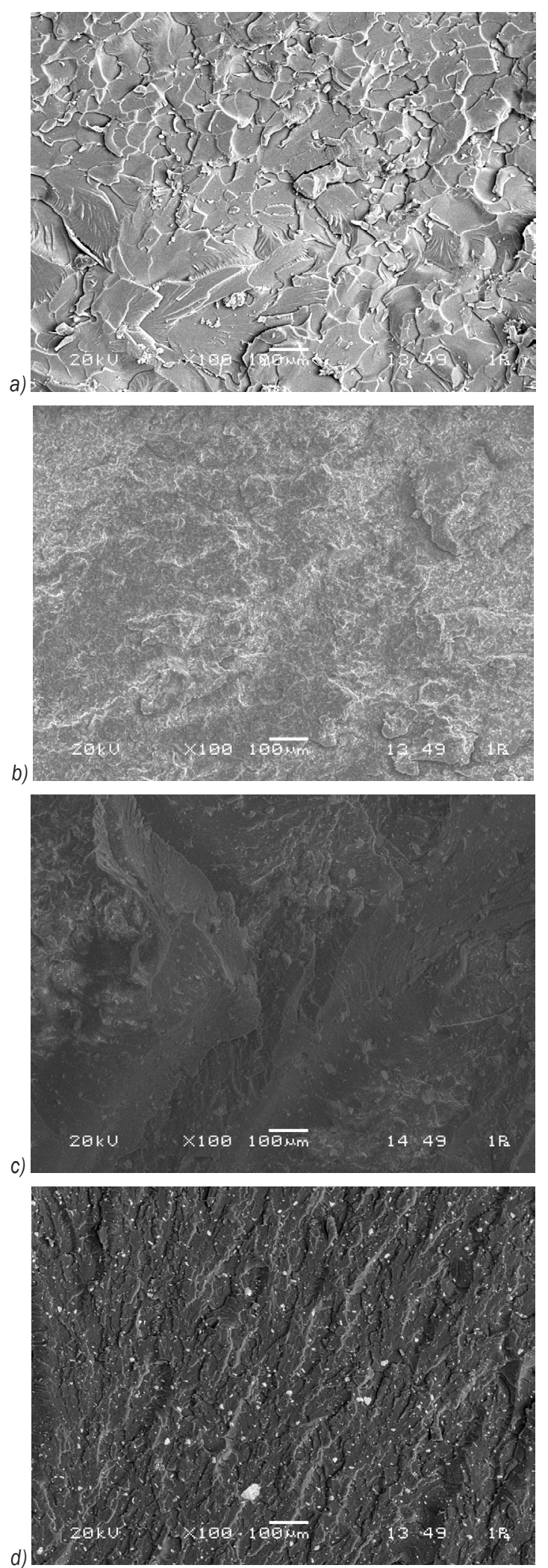

Fig. 8. Fracture surfaces of tensile test specimens, a) Pure epoxy, b) $20 \mathrm{wt} \% \mathrm{Al}_{2} \mathrm{O}_{3}$ filled, c) $20 \mathrm{wt} \% \mathrm{TiO}_{2}$ filled, and d) $5 \mathrm{wt} \%$ nano $\mathrm{TiO}_{2}$ filled filler ratio in the composites. For a $200 \%$ increase in micro $\mathrm{Al}_{2} \mathrm{O}_{3}, \mathrm{TiO}_{2}$ and fly ash filler content, there are decreases in the elongation at break values of $72 \%$, $80 \%$, and $87 \%$, respectively. In the case of nano-filler for a $300 \%$ increase in filler content, there are $39 \%$, $45 \%$ and $78 \%$ decreases in the elongation at break for nano- $\mathrm{Al}_{2} \mathrm{O}_{3}$, nano- $\mathrm{TiO}_{2}$, and nano-clay composites, respectively.

Fig. 7 shows the variations in the hardness of micro- and nano-epoxy composites with filler content. It is clear that the hardness of the composites increased with increasing filler content. Again, the rigid fillers increased the hardness of the epoxy resin. Apart from fly ash and nano clay-filled epoxy composites, all composites followed an increasing profile with increasing filler content. There is an increase of $30 \%$ to $50 \%$ in hardness value with an increase of $200 \%$ to $300 \%$ in filler contents.

Fig. 8 shows the fracture surface of the tensile specimen for pure epoxy, $20 \mathrm{wt} \% \mathrm{Al}_{2} \mathrm{O}_{3}, 20 \mathrm{wt} \% \mathrm{TiO}_{2}$ and $5 \mathrm{wt} \%$ nano- $\mathrm{TiO}_{2}$ epoxy composites. It is clear that the filler-filled composites fracture is a brittle mechanism-type failure.

\section{DISCUSSIONS}

It is clear from the results that the tensile strengths of micro-filled composites decreased with increasing filler content ratios. This could be explained as the increasing filler content caused the weak adhesion between matrix and fillers and led to the decrease of the strength of the epoxy composite. In the case of nano-filler, the drop in strength is due to the nonhomogeneous distribution of fillers at high filler ratios, which led to the agglomeration and caused stress concentration regions, leading to some drop in the strength. The decrease in nano-clay-filled epoxy composite strength could be explained by the agglomeration problem even at low filler content ratios.

The drop in elongation at break values of the composite with filler content could be explained as the elastic properties of the composite depend on the polymer matrix, which shows brittle behaviour in the presence of the fillers. This is because these fillers restrict the mobility of the polymer, and the higher the filler content is, the higher the brittleness of the composite is.

The decrease in the flexural strength of the composites could be explained by the agglomeration of the nano-fillers at higher ratios and by the presence of weak adhesive between the filler and matrix materials at high micro-filler contents. The increase in 
flexural modulus with the increasing filler content is because the fillers increased the rigidity and stiffness behaviour of the polymer composite.

In most cases, the filler increased the hardness of the composite. In the case of fly ash and nano-clay and a high filler content ratio, a small drop in hardness value was observed. This could be explained by the weakness in the adhesion between the epoxy matrix and filler materials. Lam et al. [4] explained that increasing the filler ratio caused the increasing cluster in the nano clay filled composite and a decrease in the hardness value of the epoxy composite.

In general, it is clear from Figs. 1 to 7 that the filler content has a significant effect and enhancement on most of the mechanical properties of epoxy composites but this is only effective up to certain filler ratio levels. In the case of micro-fillers, overly high levels of filler content cause a weakness in the adhesion force between the matrix and the filler, while high levels of nano-fillers show an agglomeration problem. Hence, a drop or weakness in the mechanical properties of the epoxy composite occurs.

\section{CONCLUSIONS}

From this study the following conclusions are reached:

- The tensile strength, flexural strength and elongation at break values of micro-filler $\mathrm{Al}_{2} \mathrm{O}_{3}$, $\mathrm{TiO}_{2}$, fly ash and nano-fillers $\mathrm{Al}_{2} \mathrm{O}_{3}, \mathrm{TiO}_{2}$, clay epoxy composites decreased with increasing filler ratio.

- The tensile modulus and flexural modulus of micro-filler $\mathrm{Al}_{2} \mathrm{O}_{3}, \mathrm{TiO}_{2}$, fly ash and nano-fillers $\mathrm{Al}_{2} \mathrm{O}_{3}, \mathrm{TiO}_{2}$, clay epoxy composites increased with increasing filler content.

In general, the hardness of the micro-filler $\mathrm{Al}_{2} \mathrm{O}_{3}$, $\mathrm{TiO}_{2}$, fly ash and nano-fillers $\mathrm{Al}_{2} \mathrm{O}_{3}, \mathrm{TiO}_{2}$, clay epoxy composites increased with increasing filler content.

- Epoxy composites showed brittle behaviour with the addition of the filler.

- The problem of the agglomeration of the filler is present at higher nano-filler ratios

- The results are in agreement with the results reached by [3], [4] and [13].

\section{ACKNOWLEDGEMENT}

This study was supported by the Sakarya University Scientific Research Projects Coordinatorship, with project no: 2010-50-02-004 and 2010-50-06-005.

\section{REFERENCES}

[1] Zaman, H.U., Hun, P.D., Khan, R.H., Yoon, K.B. (2012). Morphology, mechanical, and crystallization behaviors of micro- and nano-ZnO filled polypropylene composites. Journal of Reinforced Plastics and Composites, vol. 31, no. 5, p. 323329, Dol:10.1177/0731684411436126.

[2] Gao, Y., Liu, L., Zhang, Z. (2009). Mechanical performance of nano-CaCO3 filled polystyrene composites. Acta Mechanica Solida Sinica, vol. 22 no. 6, p. 555-562, D0l:10.1016/S08949166(09)60386-4.

[3] Agubra, V.A., Owuor, P.S., Hosur, M.V., (2013). Influence of nanoclay dispersion methods on the mechanical behaviour of e-glass/epoxy nanocomposites. Nanomaterials, vol. 3, no. 3, 550-563, DOI:10.3390/nano3030550.

[4] Lam, C.K., Cheung, H.Y., Lau, K.T., Zhou, L.M., Ho, M.W., Hui, D. (2005). Cluster size effect in hardness of nanoclay/epoxy composites. Composites: Part B: Engineering, vol. 36, no. 3, p. 263-269, D0l:10.1016/j.compositesb.2004.09.006.

[5] Yasmin, A., Daniel, I.M. (2004). Mechanical and thermal properties of graphite platelet/epoxy composites. Polymer, vol. 45, no. 24, p. 8211-8219, D0l:10.1016/j. polymer.2004.09.054.

[6] Sayer, M., (2014). Elastic properties and buckling load evaluation of ceramic particles filled glass/epoxy composites. Composites Part B: Engineering, vol. 59, p. 12-20, DOI:10.1016/j.compositesb.2013.11.016.

[7] Asi, 0. (2009). Mechanical properties of glass-fiber reinforced epoxy composites filled with Al203 particles. Journal of Reinforced Plastics and Composites, vol. 28, no. 23, p. 28612867, DOI:10.1177/0731684408093975.

[8] Yang, H.S., Kim, H.J., Son, J., Park, H.J., Lee, B.J., Hwang, T.S. (2004). Rice-husk flour filled polypropylene composites; mechanical and morphological study. Composite Structures, vol. 63, no. 3-4, p. 305-312, D0l:10.1016/S02638223(03)00179-X.

[9] Ibrahim, M.S., Sapuan, S.M., Faieza, A.A. (2012). Mechanical and thermal properties of composites from unsaturated polyester filled with oil palm ash. Journal of Mechanical Engineering and Sciences, vol. 2, p. 133-147, Dol:10.15282/ jmes.2.2012.1.0012.

[10] Li, M.C., Zhang, Y., Cho, U.R. (2014). Mechanical, thermal and friction properties of rice bran carbon/nitrile rubber composites: Influence of particle size and loading. Materials \& Design, vol. 63, p. 565-574, D0l:10.1016/j. matdes.2014.06.032.

[11] Imoisili, P.E., Ezenwafor, T. C., AttahDaniel, B. E., Olusunle, S.0.0. (2013). Mechanical properties of cocoa-pod/epoxy composite; effect of filler fraction. American Chemical Science Journal, vol. 3, no. 4, p. 526-531, D0l:10.9734/ ACSJ/2013/5526.

[12] Ray, D., Bhattacharya, D., Mohanty, A.K., Drzal, L.T., Misra, M. (2006). Static and dynamic mechanical properties of vinylester resin matrix composites filled with fly ash, Macromolecular Materials and Engineering, vol. 291, no. 7, p. 784-792, DOI:10.1002/mame.200600097.

[13] Raja, R.S., Manisekar, K., Manikandan, V. (2014). Study on mechanical properties of fly ash impregnated glass fiber 
reinforced polymer composites using mixture design analysis. Materials \& Design, vol. 55, p. 499-508, D0l:0.1016/j. matdes.2013.10.026.

[14] Chauhan, S.R., Thakur, S., (2013) Effects of particle size, particle loading and sliding distance on the friction and wear properties of cenosphere particulate filled vinylester composites. Materials \& Design, vol. 51, p. 398-408, DOI:10.1016/j.matdes.2013.03.071.

[15] Prakash, A.M., Kumar, G.S., Sandeep, N., Ravikumar, K. (2015). A Review on ceria epoxy nanocomposites with a new research proposal. IOSR Journal of Mechanical and Civil Engineering, vol. 12, no. 3, p. 1-3.

[16] Manjunath, M., Renukappa, N.M., Suresha, B. (2015). Influence of micro and nanofillers on mechanical properties of pultruded unidirectional glass fiber reinforced epoxy composite systems. Journal of Composite Materials, in press, DOI:10.1177/0021998315588623.
[17] Sudheer, M., Prabhu, R., Raju, K., Bhat T. (2014). Effect of filler content on the performance of epoxy/PTW composites. Advances in Materials Science and Engineering, Article ID 970468, DOl:10.1155/2014/970468.

[18] ASTM D638-10(2010). Standard Test Method for Tensile Properties of Plastics. American Society for Testing and Materials, West Conshohocken, Dol:10.1520/D0638-14.

[19] ASTM D790-10(2010). Standard Test Methods for Flexural Properties of Unreinforced and Reinforced Plastics and Electrical Insulating Materials. American Society for Testing and Materials, West Conshohocken, D0l:10.1520/D0790-10.

[20] ASTM D2583-07 (2007). Standard Test Method for Indentation Hardness of Rigid Plastics by Means of a Barcol Impressor. American Society for Testing and Materials, West Conshohocken, Dol:10.1520/D2583-07. 